\title{
International Tax Planning and Strategies of Multinational Enterprises in China
}

\author{
Zhang Zheng \\ Xi’an International University ,710077
}

Keywords: international taxation; multinational enterprise; strategy

\begin{abstract}
The globalization of economy brings the new opportunities of development for enterprises. The importance of tax planning to the multinational enterprises is obvious. But how to enhance the abilities of tax planning for improving the competitive power and increasing the incomes is a significant issue that the multinational enterprises must be considered constantly. The aim of this thesis is to discuss the specific tax planning strategy of multinational enterprises of China. By consulting some reference materials, this paper probes into the risks that existing in tax planning of multinational enterprises and the basis for tax planning, then gives some suggestions on tax planning strategy. By researching the relevant materials, it brings out that the multinational enterprises could take the reasonable forms of tax planning, improve the awareness of tax planning, avoid the risk in the tax planning, enhance the market competitiveness, and increase incomes, to achieve the purpose of tax planning.

As the most important part of the production and management of multinational enterprises, the tax planning ability of multinational enterprises must reach a certain level so that it is more considered, more suitable for the relevant laws of domestic and overseas, and the long termed strategy of the enterprise. In the process of the tax planning of China's multinational enterprises, we should give full considerations to China's tax laws and regulations of international tax treaties, the enterprise should take reasonable tax avoidance measures according to the relevant laws and regulations, and improve the economic efficiency for laying a solid foundation of its transformation and upgrading.
\end{abstract}

\section{Risks of tax planning of multinational enterprise}

\section{Strong purposes of tax planning}

The productive and managerial activities of multinational enterprises have international influence, but the specific rules of the tax system are very different in different countries. So the tax system of every country, which could be influenced by the differences, needs to be adjusted in order to decrease the accident of economic dispute and to increase the harmonious intercourse between the countries ${ }^{[1]}$. The reasonable program of tax planning could ease the burden of the enterprise in the process of international business so that it could make the international investment activities have reasonable liquidity. What's more, the tax planning of multinational enterprises is totally different with illegal tax avoiding. Tax planning is a reasonable tax avoiding method which follows the relevant tax laws and it minimizes the tax costs of enterprises, so the purpose of tax planning of multinational enterprises is very strong. Therefore, the enterprises must have an overall understanding about the international and domestic regulations, improve the abilities of tax planning constantly, and set up good international business credit in order to improve the competitive power, to lay a solid foundation for business upgrading and transformation.

\section{The risk of international tax planning is larger}

Economic globalization has brought new opportunities to the development of enterprises, has make the developmental direction of enterprises more widely, but at the same time it also increases the market competitive risk of enterprises. The reasons is that when the multinational enterprises make the tax planning, the planning is aimed for the business which will happen in future, this certainty increases the risk of the enterprises' tax planning. Compared with the domestic enterprises, 
the multinational enterprises should consider more factors, if the enterprise doesn't consider and assess all the factors in the process of tax planning in all round, the program of tax planning could be difficult to play a practical role, so that the tax planning could not reach the goals of itself ${ }^{[2]}$. In addition, during the implementation of the planning, if the international tax legal system will be changed in large extent, the practical significance of tax planning will be reduced accordingly. Therefore, the risk of tax planning of multinational enterprises is high, it is hard to control the risk overall, it needs to improve the program of the planning and enhance its timeliness.

\section{The bases of international tax planning for transnational enterprises in China}

\section{Tax jurisdiction}

Tax jurisdiction is the power of taxation of a country or a district. Generally speaking, the contents of tax jurisdiction are different in different countries and districts; the basic system of taxation is different as well. In the processes of tax planning, the multinational enterprises not only need to consider the domestic tax system, but also the international tax agreements and other country's tax agreement. The tax panning of multinational enterprises could not conflict with any tax law no matter it is domestic, international or overseas. Otherwise, the risk could be large.

\section{International tax agreement of multinational enterprises}

International tax agreement is a regime, which is agreed by different countries, for solving the problems of distribution of tax interests between the different countries. These regimes are some agreement that is discussed by the two relevant counties and then come to be an agreement. In the items of international tax agreement, withholding tax is the most important part, so the rate of withholding tax is generally low, it could deduct the income tax of the contracting country. Therefore, international tax agreement will become the important reference for selecting the project of investing to multinational enterprises, and provides more space to the enterprises for tax planning. For example, there are more than eighty countries have signed the international tax agreements with China.

\section{The strategies of international tax planning of China's multinational enterprises.}

As the most important component of multinational enterprise's business activities, the benefits of tax income are very important. In addition, to make a good tax planning, it could improve the market competitive power of multinational enterprises. For example, CITIC Group, Shanghai BAOSTEEL group, SINOPEC Group and so on, these national ventured enterprises of China, their tax planning, which is highly required, is at a high level, and tax benefits is crucial in the business activities of those enterprises. There are essentially differences between the tax planning of multinational enterprises for decreasing the tax load, which follows the domestic and international tax laws, and illegal tax avoidance. As the constantly development of economy of China and expansion of globalization of economy, the quantity of multinational enterprises of China is creasing step by step, but it is still weak in the respects of abilities of tax planning, and the awareness of tax planning than that of the developed countries. The multinational enterprises of China should properly draw on the experiences of the developed countries about enterprise's tax management, set up the special tax administration departments, where the professional talents of tax planning management works ${ }^{[3]}$. Based on this, the domestic multinational enterprises also need to have a specific awareness of tax planning, and the overall understanding of the importance of tax management, to learn the experiences about tax planning of the developed countries, and to consider the object conditions of China in order to improve the relevant methods of tax planning which could service the development of the enterprises well and improve their key market competitive power.

Although make a perfect tax planning could get more economic benefit, but it still need to undertake and face more risk of tax management: the environment changes quickly, and it changes in a large extent as well, for example, the Tax Base Erosion and Profit Shifting programs, which are 
started in 2015, have enhanced the requirement of open, and shifted the key point to the virtual business activities. In 2016, the European countries enhance the tax management level of multinational enterprises once more. These phenomena totally show that the environment of international taxation is so complicated that the requirement of management is more restrict, and the risk of multinational enterprises is increasing ${ }^{[4]}$. What's more, the tax planning of multinational enterprises involves lots of domestic, international, overseas tax agreements and laws, and the fulfillment of tax planning needs a long time to achieve, tax planning is kind of forecast which budgets an enterprise's management and tax conditions of a period in the future , If the planning time is not accurate, or the managerial methods of international tax have changed greatly in the planning period, it will make the cost of the enterprise to increase, and the practical significance of tax planning will be relatively reduced. Therefore, to make a tax planning program, the enterprise needs a scientific judgment on the direction of the changing economic forms and the general legislations. For achieving those above, tax planning becomes very difficult.

As it is mentioned above, international taxation, which has widely influence, is changing quickly, so the tax planning of multinational enterprises is facing bigger risk than anytime before. However, it could make the best use of the flexibility of international tax planning to improve the tax planning programs of enterprises. For example, it could set up specialized financial institutions for appropriate tax avoidance; make the best use of the preferential tax policies to reduce the actual tax rate, and then turn business profits back to domestic by using the way of tax avoidance once more in order to avoid taxing in domestic ${ }^{[5]}$. But, the contents of tax planning should cater with the rules of domestic tax planning; choose the tax planning methods that should be diverse in order to improve the level of tax planning abilities; and follow the rules of tax planning that are made by every county; reduce the risk of tax planning of the enterprises.

International letting and hiring is a relative important method that is used for tax planning of multinational enterprises. It not only can enjoy the preferential tax policy, but also can use for reducing the profits of enterprises by the way of paying for the rent to the loaner so that it can reduce the tax amount of the enterprises. Therefore, it is very important to use this method of international letting and hiring in tax planning of multinational enterprises. At present, the relative united methods of lease are transfer lease and invest lease, the first kind of lease means that the enterprises purchase assets from enterprises with higher tax rates, and then transfer it to other countries which have a lower tax rate. After that, the overseas enterprises transfer it to the enterprises which is in a higher tax rate country at the highest leasing price, at the some time, transfer the incomes form the country which has higher tax rate to the country that tax rate is lower, and the leaser and lessee could withdraw the relevant taxes many times, this brings that the taxation of the enterprise is lowest for purchasing the assets ${ }^{[6]}$. The second kind of lease is the way of transferring direct investment to lease in order to increase the cost of sub-company, and then reduce the amount of tax of the enterprise.

The confirmation of taxes usually is the result of business accounting, the result of business accounting in enterprises; it also is the key content of tax auditing, therefore, the reasonable way of accounting has important influence to the tax and profit of the enterprise. To the multinational enterprises, in tax planning programs, reasonable choice of accounting methods will promote the rationality and legitimacy of tax planning. First of all, multinational enterprises should clearly understand the new accounting system and rules of accounting, consider the actual business needs of the enterprises to choose the most appropriate accounting method in order to reduce the burden of enterprises, increase enterprises’ economic benefits.

\section{Conclusion}

Above all, it is the important component that the profits from the tax planning of the multinational enterprise. But the tax planning becomes very difficult because of the improvement of tax planning abilities of the multinational enterprises and the requirement of legitimacy of tax planning. However, reasonable tax planning can reduce the tax burden of enterprises; improve its market competitiveness; improve its economic efficiency, so it is worth to enhance the tax planning 
level of multinational enterprises.

\section{Reference Materials:}

[1]Li Xiaojing. Analysis on international tax planning and the relevant strategies of China[J]. Money China, 2015, 24:369-371.

[2]Pei Xiaojun. Study on the strategies of international tax planning of multinational company[J]. Money China, 2016,05:309.

[3]Wang Peili. Research on tax planning strategy of multinational enterprises[J]. ACCOUNTING LEARNING, 2016,15:155+157.

[4]Wang Lu. Study on The path of international tax planning for multinational enterprises----take Apple Inc. for example[J]. Manager Journal, 2016,24:72-73.

[5]Zhang Zhenguang. Analysis on the key points of multinational operation and international tax planning[J]. TIMES FINANCE, 2017,12:22-23.

[6]Wang Jinhong. Study on the multinational tax planning of construction enterprise[J]. Finance and Accounting for International Commerce, 2017,01:57-60. 